\title{
Çocukluk Deneyimleri, Azim ve Girişimcilik Niyeti İliş̧kisi: Sağlık Yönetimi Öğrencileri Üzerinde Bir İnceleme
}

\section{Relationship of Childhood Experiences, Grit and Entrepreneurship Intention: A Research on Health Management Students}

\author{
Arş. Gör. Mehmet Ali TAŞ ${ }^{(1)}$, Dr. Öğr. Üyesi Necla YILMAZ ${ }^{(D)}$
}

\begin{abstract}
$\ddot{O} z$
Girişimcilik niyeti, karakteristik yapısı gereği hem kişilik özelliklerinden hem de içinde yaşanılan çevresel bağlamlardan etkilenmektedir. Buradan hareketle bu çalışmanın amacı; Sağlık Yönetimi öğrencilerinin çocukluk dönemlerinde, ebeveynlerinin olumsuz tutum ve davranışları neticesinde edindikleri deneyimlerin, girişimcilik niyetinin ve azmin ilişkisini incelemektir. Bu amaca yönelik olarak, Süleyman Demirel ve Burdur Mehmet Akif Ersoy Üniversitelerinin İktisadi ve İdari Bilimler Fakültelerinde öğrenim gören Sağlık Yönetimi Bölümü 4. Sınıf öğrencileri üzerinde bir araştırma yürütülmüştür. Toplamda 226 kişiden anket tekniği kullanılarak veri toplanmıştır. Bu veriler AMOS 23 ve SPSS 22 paket programları kullanılarak analiz edilmiştir. Elde edilen bulgulara göre çocukluk deneyimleri azmi olumsuz etkilemekte ancak girişimcilik niyetini anlamlı bir şekilde etkilemediği saptanmıştır. İlaveten azmin, girişimcilik niyetini anlamlı ve olumlu etkilediği ortaya çıkmıştır. Ölçeklerin boyutları bağlamında da önemli bulgular elde edilmiştir. Çocukluk dönemlerinde maruz kalınan boyun eğdirici, tehdit edici ve değersizlik içeren anılar, bireylerin yetişkinlik dönemlerindeki hayatlarına da yansımaktadır. Bu bağlamda olumsuz anılar bazı durumlarda girişimcilik niyetini ve hedeflere ulaşma noktasında azimle gayret etmeyi baltalarken, bazen de itaat zincirlerini kırma, özgürlük ve öz kontrol gibi duyguların ortaya çıkmasını destekleyebilmektedir. Bunun yanında ayrıca uzun vadede gayrette ısrar etmek suretiyle azim göstermenin girişimcilik niyetini besleyebildiği görülmektedir.
\end{abstract}

Anahtar Kelimeler: Çocukluk deneyimleri, azim, girişimcilik niyeti, sağlık yönetimi

Makale Türü: Araştırma

\begin{abstract}
Entrepreneurship intention is affected by both the personality traits and the environmental contexts in which it grows due to its characteristic structure. From this point of view, the relationship between entrepreneurship intention, grit and childhood experiences that students acquired as a result of their parents' attitudes and behaviors were tried to be revealed in this study. For this purpose, a research was carried out on the 4th grade students of the health management department studying at the Faculty of Economics and Administrative Sciences of Süleyman Demirel and Burdur Mehmet Akif Ersoy Universities. A total of 226 people collected data using the survey method. This data set was analyzed with AMOS 23 and SPSS 22 package programs. According to the findings, childhood experiences affect the grit negatively. However, it has determined that it has no significant effect on entrepreneurship intention. In addition, it has been revealed that grit has a significant and positive effect on entrepreneurial intention. Important findings were also obtained in terms of the dimensions of the scales. Submissive, threatening and worthless memories exposed in childhood are also reflected in the lives of individuals in adulthood. In this context, negative memories sometimes undermine the entrepreneurial intention and grit in reaching goals, while sometimes they can support the emergence of feelings such as breaking the chains of obedience, freedom and selfcontrol. In addition, it is seen that grit by insisting on long-term effort can feed entrepreneurial intention.
\end{abstract}

\footnotetext{
${ }^{1}$ Burdur Mehmet Akif Ersoy Üniversitesi, İktisadi ve İdari Bilimler Fakültesi, matas@mehmetakif.edu.tr.

${ }^{2}$ Süleyman Demirel Üniversitesi, İktisadi ve İdari Bilimler Fakültesi, neclabardak@ @su.edu.tr.
} 
Keywords: Childhood experiences, grit, entrepreneurship intention, health management

Paper Type: Research

\section{Giriş}

Ülkeler açısından oldukça önemli ve ekonomilerin itici bir gücü olarak görülen girişimciliğin geliştirilmesi (Butz vd., 2018, s. 2; Nejat ve Basım, 2012, s. 21), bireysel ve ulusal anlamdaki bir ekonomik kalkınma için hayati öneme sahiptir (Farrukh vd., 2017, s. 304). Girişimcilik faaliyetlerinin istihdam sorunlarına çözüm üreten ekonomik bir fonksiyon içermesinin yanı sıra (Aytaç ve İlhan, 2007, s. 101; Drennan vd., 2005, s. 232) sosyal ve kültürel fonksiyonlarının bulunması nedeniyle özellikle günümüzde üzerinde durulması gereken bir konu olarak görülmektedir.

Özellikle Türkiye'de genç nüfusun yoğun olması nedeniyle gençlerin nasıl istihdam edileceği konusunda ciddi sorunların olduğu düşünülmektedir. Üniversitelerden her yıl, mezuniyet sonrası işsiz kalma kaygısı ile yüzlerce genç mezun olmaktadır. TÜíK (2020) verilerine göre, Türkiye'nin 2020 yılı temmuz ayı işsizlik oranı \%13.4 olarak açıklanmıştır. Diğer yandan 2020 yılının ilk iki çeyreğinde kamu sektörüne istihdam edilen toplam kişi sayısının ise 9.463 kişi olduğu görülmektedir. Özellikle belirsizliğe toleransın ve risk almanın düşük olduğu Türk toplumunda (Sığrı ve Tığl1, 2006: 331) kamu sektörü, gençler için oldukça cazip görülebilmektedir. Ancak kamu sektörünün kısıtlı istihdam olanakları, gençlerde ekonomik, sosyolojik ve psikolojik sorunların ortaya çıkmasına sebep olabilmektedir. Bu nedenle gençlerin istihdam olanaklarını geliştirmek adına girişimciliğin önemi büyüktür. Üniversite müfredatında her ne kadar girişimcilikle ilgili farkındalığı geliştirmek, ekonominin ihtiyaçlarına uygun girişimcinin bilgi, kapasite, beceri ve tutum ile niyetlerin geliştirilmesine olanak tanımak adına dersler verilse de (Farrukh vd., 2017, s. 304) girişimcilik niyeti veya eylemleri, ülkenin ekonomik durumu, kültürü, aile geçmişi, ebeveyn tutum ve davranışları gibi dış kaynaklardan etkilenebilmektedir (Rachmawan vd., 2015, s. 417-418). Ayrıca, tüm bu faktörlerin girişimcinin gelişimi üzerinde de güçlü bir etkisi olduğunu göstermektedir (Rachmawan vd., 2015, s. 420422).

Girişimcilerin çocukluk deneyimlerinin zorluklarla dolu olduğu, yoksulluk, güvensizlik, ihmal (Collins ve Moore, 1964; Drennan vd., 2005, s. 233-234) ve ebeveynlerin boşanması, bir ebeveynin ölümü, ailenin maddi zorlukları, ciddi hastalık, terk edilme ve şiddet gibi kişisel trajedilerle karakterize edildiği görülmektedir (Cox ve Jennings, 1995, s. 5). Bireylerin çocukluk döneminde yaşadıkları travma ve olumsuz deneyimlerin yetişkinlik dönemlerine yansıdığı ileri sürülmektedir (Akın vd., 2013, s. 1542; Gouveia, vd., 2016, s. 54). Bu deneyimlerin bireyler tarafından ileriki yıllarda hatırlanması ise yetişkinlik dönemlerinde fizyolojik, psikolojik ve sosyal açıdan kritik sonuçlar doğurabilmektedir (Richter vd., 2009, s. 171). Ailenin yapısı, tutum ve davranışları çocukların kariyerleri üzerinde net bir etkiye sahip olduğu da bilinen bir gerçektir (Cox ve Jennings, 1995, s. 4).

Bu nedenle girişimcilik olgusunun aile gibi önemli sosyolojik bir kurumdan soyutlanarak açıklanması güçtür (Yener, 2018, s. 870). Aile; çocuğa özgüven, öz sayg1 ve destek gibi önemli imkânlar sağlayabilmektedir. Bu noktada aile, girişimcilik için önemli bir potansiyel kaynak olarak görülmesi yerinde olacaktır (Aldrich ve Cliff, 2003, s. 580). Aile bazen çocuklar için risk alma ve cesur davranma gibi bir atmosfer yaratırken bazen de muhafazakâr ve rollerine bağımlı olmalarında kritik bir rol oynamaktadır. Bu sebeple aile kurumu, çocukların şekillenmesinde önemli bir yapıtaşıdır (Yener, 2018, s. 871). Dolayısıyla ebeveynlerin tutum ve davranışlarının şekli başta gençler olmak üzere birçok insanın girişimci olma isteğini geliştirebildiği gibi baltalama ihtimali de bulunmaktadır. Bunun önemli nedenleri arasında ebeveynlerin özgüven ve azim aşılama noktasında yetersiz kalmasıyla açıklanacağı ileri sürülmektedir. Nitekim azim, çeşitli faaliyetlerde başarının bir yordayıcısı olarak gösterilmektedir (Butz vd., 2018, s. 1). 
Girişimcilik ile ilgili araştırmalarda genellikle eğitim ve ailenin ekonomik geçmişine vurgu yapıldığı görülmektedir. Ancak erken çocukluk döneminde elde edilen başarı, yetişkinlikte girişimcilik potansiyelini etkileyebileceği ileri sürülmektedir. Çocukluktan başlayarak bu geniş faktörleri hesaba katmamak, girişimci beklentilerin eksik yorumlanmasına yol açabilmektedir (Jayawarna vd., 2014, s. 918-920). Buradan hareketle iş kurma niyeti olarak tanımlanan girişimciliğe giden yolu daha iyi değerlendirmek için bu çalışma yapılmıştır.

$\mathrm{Bu}$ araştırmada girişimcilik niyetlerinin belirleyicileri oldukları düşünülen azim ve çocukluk deneyimlerinin iş kurma niyetlerine yönelik tutumlar üzerindeki etkisine odaklanılmaktadır. Önceki çalışmalar göz önüne alındığında, çocukluk deneyimleri, azim ve girişimcilik niyeti ilişkisini bir arada ele alan bir çalışmaya rastlanmamıştır. Bu değişkenler arasındaki ilişkinin incelenmesi, çocukluk deneyimlerinin ve azimli olmanın bu niyeti şekillendirmedeki rollerinin ne olduğunun yansitılması amaçlanmaktadır. Sağlık Yönetimi Bölümü öğrencilerinin kamu kurumlarına istihdam edilmeleri noktasında kadro sorunlarının olması nedeniyle girişimcilik niyetlerinin olup olmadığı merak konusudur. Bu sebeple sağlık yönetimi bölüm öğrencileri üzerinde bir araştırma yapılması planlanmıştır. Diğer yandan Nejat ve Basım (2012: 22), günümüzde girişimcilik niyeti sadece işletme bölüm öğrencilerinde değil, yelpazesi genişleyerek diğer bölüm ve fakültelerinin öğrencilerinde de girişimci özelliklerinin olması gerektiğini ileri sürmektedirler.

\section{Kavramsal Çerçeve}

\section{1. Çocukluk Deneyimleri}

Aile kurumu, çocukların filizlendiği bir ortamdır. Çocuğun sosyal ortamlardaki olumlu veya olumsuz davranışları bu ailenin mesajını taşımaktadır. Bu nedenle ebeveyneler ile çocuk arasındaki olumsuz iletişim çocuğun yetişkinlik yaşamında birtakım olumsuzlukların temel kaynağı olabileceği öne sürülmektedir. İşlevsiz ebeveynlik stillerinin, çocuğun ruhunda kabuk bağlamayan derin yaralar açabildiği görülmektedir (Webb vd., 2007, s. 1144). Dolayısıyla çocukların ebeveynleriyle etkileşimleri ve kurdukları ilişkiler önem arz etmektedir (Gouveia vd., 2016, s. 54).

Bazı ebeveynler çocuklarını kontrole ihtiyaç duyan ve akıl yürütme olasıllğg düşük olan astlar olarak algılayabilir ve tehdidi bir kontrol aracı olarak kullanabilmektedir. Bu nedenle, çocuklar kendilerini güvende hissetmek yerine, stres ve korkunun olduğu ortamlarda büyüyebilmektedir. Sonuçta çocukların ebeveynleri ile korku temelli bir iletişim kuracağı ileri sürülmektedir. Çocukların gelişimsel süreç içerisinde ebeveynlerinden baskı görmesi, sert eleştirilere, reddedilmeye ve ihmal edilmeye maruz kalmas1, kendilerinin önemsenmediklerini düşündürmektedir. Bu durum şüphesiz çocukların sorgulamadan, itaatkar, kaçınmacı, başkalarına bağımlı ve emri uygulama gibi zorlanmış ve isteksiz olmalarına zemin hazırlamaktadır (Gouveia vd., 2016, s. 55; Gilbert vd., 2003, s. 108-109). Bu durumun sonuçları yetişkinlik dönemlerinde görülmektedir. Bireyler kendini değersiz, savunmasız ve aşağılanmış hissederek, çevrelerini tehdit ve güvenlik açısından sürekli değerlendirmektedir. Aynı zamanda başkalarını potansiyel düşman olarak görmeleri söz konusu olmaktadır (Gouveia vd., 2016, s. 55). Bu durum tehdit edici çevrede çocukların savunma amaçlı bir yönelim geliştirmelerine ve başkalarına zarar verme, utanma veya reddetme mekanizmalarına odaklamaktadır (Irons ve Gilbert, 2005, s. 326). Bunun sonucunda çocukların ilerleyen dönemlerinde yaşayacakları zorluklara karşı kırılganlık eşiklerinin düşük olacağı ifade edilmektedir (Gouveia vd., 2016, s. 55). Böylelikle çocukların akranları tarafından daha az sevilebileceği ve daha fazla reddedilebileceği bilinmektedir (Irons ve Gilbert, 2005, s. 327). Bireylerin, çocukluk dönemlerinde değersiz, korkmuş ve bağımlı bir şekilde davranması gerektiğini anımsatan bu anıları, hayatları boyunca hatırlamaya ve her yere taşımaya devam edeceği ileri sürülmektedir. (Richter vd., 2009, s. 174). Yetişkinlikte görülen düşük öz yeterlilik; özgüven eksikliği, karamsarlık, umursamazlık gibi sonuçları beraberinde getirmektedir (Irons ve Gilbert, 2005, s. 325-326). Nitekim araştırmalar, ebeveynlerle olumsuz deneyimlerin hatırlanması ve depresyon ile güvensiz bağlanma arasında tutarlı bir ilişki olduğunu 
göstermektedir (Irons vd., 2006, s. 297). Bu durumun çocukların plan yapma, stratejiler üretme ve problem çözme yeteneklerini zayıflattığı ileri sürülmektedir (Hong, 2007, s. 279).

Diğer yandan erken çocukluk deneyimlerinde sıcak ve güvenli ortamların benlik saygısı, mutluluk ve psikopatolojiye karşı daha düşük bir kırılganlık riski, yüksek öz yönetim becerileri ve özgüven ile ilişkili olduğu ifade edilmektedir (Richter vd., 2009, s. 171-172). Güvenli bağlanan çocuklar daha toplum ve öz benlik yanlısı olmaktadır. Stresle daha etkili baş edebilmektedirler. Güvenli bağlanan çocuklar, kendileri ve diğerleri hakkında göreceli olarak iyi hissettikleri için, hızla iş birliği ve destekleyici ağlar oluşturmaktadırlar (Irons ve Gilbert, 2005, s. 326; Akın vd., 2013, s. 1542; Williams vd., 2009, s. 1063).

$\mathrm{Bu}$ çalışmada üç çocukluk deneyiminden bahsedilmektedir. İlki boyun eğdirici anılar; kendini bağımlı hissetme ve itaatkâr bir şekilde hareket etme ile ilgili bir durumu açıklamaktadır. Çocuk burada ebeveynlerin kendisine kızmasından endişe duymaktadır. Söylenene itaat etmezse dışlanacağını düşünmektedir. İstemese de diğerleriyle aynı fikirde olmak zorunda olduğunu hissetmektedir. İkincisi tehdit edici anılar; güçlü ve baskın ebeveynlerle etkileşimde algılanan tehdit ve korkulu anıları ifade etmektedir. Çocuk incinmekten korktuğu için ebeveynlerinden uzak durmaktadır. Ceza yoluyla sürekli kontrol altında tutulmaktadır. Aile içinde her an gergin bir hava ortaya çıkmaktadır. Üçüncüsü ise değersizlik içeren anılardır. Çocuğun aile fertleri arasındaki önemlilik derecesini ifade etmektedir. Kendini savunamayacağını hissetmesi durumudur. Ebeveynlerin yanında kendini rahat ve huzurlu hissedip hissetmemesi ile ilgilidir (Gilbert vd., 2003, s. 11; Gouveia vd., 2016, s. 55).

\subsection{Azim}

Hayatta bir amaca tutunmak; bireylerin cesur olmalarını ve vizyon sahibi özelliklerini geliştirmektedir. Bu nedenle hangi bireylerin başarıya eğilimli olduklarını belirlerken, en belirgin adaylar uzun vadeli hedefleri için tutkusu olan ve engeller karşısında bile kazanma arzusunu yitirmeyenler olduğu ileri sürülmektedir (Hill vd., 2016, s. 258). Çünkü başarı güçlü bir iradeye bağlıdır (Sarıçam vd., 2016, s. 928). Amaç ve hedef yönelimi büyük ölçüde içsel motivasyonla çabalamayı gerekli kılmaktadır. Başarısızlıkta bile kararlılıkla ve odaklanarak başarılı olmak için azmin önemli bir unsur olduğu ileri sürülmektedir (Black, 2014, s. 6; Duckworth vd., 2007).

Azim; zorluklar, başarısızlıklar ve sıkıntılar karşısında bile çabayı ve ilgiyi korumayı gerektirmektedir. Buradan hareketle azim unsurunun iki temel boyuttan oluştuğu ifade edilmektedir. Birincisi; açık bir şekilde tanımlanmış uzun vadeli hedeflere odaklanmaya devam eden ilgide tutarlılıktır. İkincisi ise, yol boyunca zorlukların ve engellerin üstesinden gelmek için gösterilen gayrette 1srar boyutudur (Duckworth vd., 2007, s. 1087; Mueller vd., 2017, s. 263; Sarıçam vd., 2016). Zaman içinde uzun süreli hedef arayışı, bireylerin gerçekten istisnai başarılara ulaşmasını sağlayan temel bir faktördür. Özellikle girişimciler için uzun vadeli hedeflere devam etmeye odaklanması yönüyle benzersiz bir özelliktir (Mueller vd., 2017, s. 263). Süreç boyunca dikkat dağıtıcı ve zorlukların üstesinden gelme istekliliğini de yansıtmaktadır (Mueller vd., 2017, s. 265).

Bireyin mücadele karşısında zahmetli bir şekilde devam etme yeteneğinin bir ölçüsü olan azim, başarının anahtarıdır (Hodge vd., 2018, s. 448-449). Azim, uzun vadeli hedeflere sebat ve tutku ile ilerlemeyi sağlamaktadır. Zorluklara rağmen çaba gösterme kapasitesi ve enerjisidir. Yetenekleri geliştirmeye yönelik çabalar için bir yakıttır (Sharda, 2019, s. 698-699; Duckworth vd., 2007, s. 1087). Azim; dayanıklı ve sabırlı olmayı öğretmektedir (Sarıçam vd., 2016, s. 928). Azim, motivasyonu koruyan bir yönü bulunmaktadır (Black, 2014, s. 10). Azmin bu avantaj1 sayesinde bireyler, aksilikler ve başarısızlıklar olsa bile yıllarca amaçlarına tutkuyla sadık kalabilmektedir (Butz vd., 2018, s. 5). Bu nedenle azim, uzun vadeli bir hedefe bağl1lı̆g sağlamaktadır (Arco-Tirado vd,, 2019, s. 8).

Azim aynı zamanda yaşam doyumunun da bir göstergesidir (Arco-Tirado vd., 2019, s. 4). Yüksek düzeyde azim, öğrencilerin refahını artırdığı ve olumsuz sosyal bağlamdan daha az 
etkilenmelerine zemin hazırladığı ileri sürülmektedir. Çünkü kendi uzun vadeli hedeflerine daha fazla odaklanmaktadırlar (Ma vd., 2020, s. 4). Bu nedenle yüksek azim ile yüksek başarı arasında önemli bir ilişki mevcuttur (Vela vd., , s. 291; Mueller vd., 2017, s. 262). Buradan hareketle azim unsurunun, girişimcinin başarısını açıklayan önemli bir değişken olabileceği düşünülmektedir.

\subsection{Girişimcilik Niyeti}

Girişimcilik; firsatların belirlenmesi, değerlendirilmesi ve araştırılmasıdır. Bu nedenle girişimciliğin nüfus entegrasyonunu ve sosyal hareketliliği kolaylaştıran bir mekanizma olduğu ileri sürülmektedir (Obschonka vd., 2017, s. 487). Ekonomik büyümenin bel kemiğidir (Geldhof vd., 2014, s. 86). Bireysel açıdan, bireyin başkaları tarafından göz ardı edilen yeni firsatları algılama yeteneği, uyanıklığı veya eylemi olarak tanımlanmaktadır (Obschonka vd., 2017, s. 489). Niyet ise; insanın iç âleminde gerçekleșen, geleceğe dair bilişsel bir karar verme durumunu ifade etmektedir (Sezer, 2013, s. 51). Niyet, kişisel davranışın tahmin edilmesini sağlamaktadır. Eylem ise, bir sonucu ifade etmektedir (Farrukh vd., 2017, s. 304). Bu nedenle niyet bir işin kurulmasındaki ilk basamak olarak kabul edilmektedir (Önay vd., 2017, s. 57). Buradan hareketle girişimcilik niyeti, gelecekte kendi başına bir girişimci kariyerine hazırlanmak ve daha sonra başlamak için az çok somut bir plan olarak görülmektedir (Obschonka vd., 2017, s. 489). Kişinin kendi işini planlaması ve kurması için gerekli olan çabayı göstermesi ve faaliyetleri sergilemesidir (Nejat ve Basım, 2012, s. 22). Girişimcilik niyeti, bir ürün veya hizmeti geliştirmek üzere çeşitli faaliyetler olarak da düşünülebilir (Carr ve Sequeira, 2007, s. 1091). Netice itibariyle niyet, girişimci olmak için ifade edilen davranışın ön aşamasıdır ve bir kişinin bir girişim geliştirmeye ilgisini göstermektedir (Karimi, 2020, s. 331).

Girişimcilik niyeti, bir iş kurmaya ve gelecekteki başarıyı yakalamak için girişimsel eyleme yol açabilir (Butz vd., 2018, s. 2). Ancak planlanmış davranış teorisinde (Ajzen, 1991) bu niyetin; tutum, öznel normlar ve algılanan kontrol unsurları tarafından şekillendirildiği ileri sürülmektedir. Bireyler, bir davranışa yönelik tutumlarını, sosyal baskı algısını ve bu davranış1 gerçekleştirme güçlüğü/kolaylığı ile ilgili yeteneklerini değerlendirmektedirler (Carr ve Sequeira, 2007, s. 1091). Bu açıdan bakıldığında girişimcilik niyetinin inşa edilmesi için kişinin bu unsurlar çerçevesinde hareket ettiği ileri sürülmektedir (Farrukh vd., 2017, s. 304). Fakat girişimcilik niyetleri üzerinde kişisel niteliklerin ve bağlamsal özelliklerin ortak rolleri bulunmaktadır. Niyetlerin en iyi davranış öngörücüsü olduğu varsayıldığından bu niyetleri etkileyen parametrelerin daha fazla olduğu ve derinlemesine anlaşılması, girişimci davranışın değerlendirilmesinde önemli olacağ i ileri sürülmektedir (Karimi, 2020, s. 331). Bunlardan bazıları ise cinsiyet, tanınma ihtiyacı, başarı yönelimi, deneyim ve ebeveynlerin rolü (Geldhof vd., 2014, s. 81), algılanan kontrol odağı, başarı ihtiyacı, (Chaudhary, 2017, s. 180), öz-yeterlik, dayanıkl1lık, iş deneyimi (Bullough vd., 2014, s. 486), ailenin ekonomik geçmişi, kişilik, azim, yenilikçilik vb. faktörler olduğu ileri sürülmektedir. Bunların girişimcilik başarısı ile önemli düzeyde ilişkilerinin olduğu görülmektedir (Wolfe ve Patel, 2016, s. 855; Arco-Tirado vd., 2019, s. 2). Öte yandan girişimcilerin genellikle dişa dönük, sosyal becerileri gelişmiş, öz yeterliliği yüksek ve özgüven sahibi oldukları ifade edilmektedir (Schoon ve Duckworth, 2012, s. 1720; Farrukh vd., 2017, s. 306). Öyle ki güçlü bir öz-yeterlik duygusu olmadan, bireyin zorluklar karşısında harekete geçmesi ya da azim göstermesi zorlaşmaktadır (Bandura, 2002, s. 2; Carr ve Sequeira, 2007, s. 1093).

\section{4. Çocukluk Deneyimleri, Azim ve Girişimcilik Niyeti İlişkisi}

Çocukların büyüdüğü ortam, onların şekillenmesinde rol oynamaktadır. Araştırmalar, aile deneyimlerinin insanların yaşamları boyunca benimsedikleri değerler, tutumlar ve davranışlar üzerinde güçlü bir sosyalleşme etkisi oluşturduğunu göstermektedirler (Carr ve Sequeira, 2007, s. 1090). Bu nedenle geçmiş deneyimler, gelecekteki davranışların en iyi tahmin mekanizmalarıdır. Geçmiş deneyimlerin, tutum oluşumu ve öznel normlar yoluyla davranışsal niyeti etkilediği ileri sürülmektedir (Ajzen, 2002; Carr ve Sequeira, 2007, s. 1092). Kişisel ilgi ve 
tercihlerin çocukluk deneyimlerinden etkilenebileceği, girişimcilik eğiliminin farklı olduğu ve erken yaşlarda öne çıktığı ileri sürülmektedir (Schoon ve Duckworth, 2012, s. 1720).

Destekleyici ebeveynlere sahip olmak, girişimcilik niyetinin önemli bir basamak taş1 olabileceği ileri sürülmektedir. Ebeveynler, rol modeli olarak hareket ederek ve çocuklarını belirli ilgi ve yeterlilikler geliştirmeye teşvik ederek güçlendirebilecekleri ileri sürülmektedir (Schoon ve Duckworth, 2012, s. 1722). Yaygın olarak kabul gören bir görüşe göre de çocukluk deneyimlerinin, iş hayatındaki diğer kişilerin ve önceki iş deneyimlerinin girişimcilikle ilgili tutumların gelişimini etkilemektedir (Carr ve Sequeira, 2007, s. 1092).

Özellikle, gelişmekte olan ülkeler bağlamında, ebeveynlerin destek ve tutumları çocukların girişimci tutumlarını şekillendirmede daha da önem kazanmaktadır. Çünkü bunların çoğu veya hepsi eğitim ve diğer destekler için ailelerine bağımlıdır. Bireyin kariyer seçiminde başkalarının, özellikle ailenin desteğinden mahrum bırakması girişimcilik niyetinin belirlenmesine neden olmaktadır (Sharma, 2014, s. 3; Jagannathan vd., 2017, s. 6). Geçmişte girişimci ebeveynlerle büyüyen çocukların girişimci bir kariyer seçme eğiliminde oldukları savunulmaktadır (Sharma, 2014, s. 5). Ailenin destekleyici tutum ve davranışları çocukların girişimcilik niyetleri için bir kuluçka görevi görmektedir. Çocuk büyüdükçe girişimcilik seçeneği güçlü bir tercih haline geleceği ya da gelmeyeceği ileri sürülmektedir (Farrukh vd., 2017, s. 304). Buradan hareketle şu hipotezler geliştirilmiştir:

H1: Çocukluk deneyimleri girişimcilik niyetini anlaml şekilde etkilemektedir.

Hla: Boyun eğdirici anılar girişimcilik niyetini anlaml şekilde etkilemektedir.

H1b: Değersizlik içeren anılar girişimcilik niyetini anlamlı şekilde etkilemektedir.

H1c: Tehdit edici anılar girişimcilik niyetini anlaml şekilde etkilemektedir.

Çocukların ileriki yaşlarda farkındalık bilinciyle hareket etmesi çocuklukta yaşadıkları deneyimlerin etkisi büyüktür (Şahin, 2018, s. 64). Çocukların, aileleri tarafından eylemleri desteklediğini algılamaları halinde, daha yüksek düzeyde girişimcilik niyetine sahip oldukları ileri sürülmektedir. Pozitif ve hemen desteklenen girişimci davranışlar, yeni bir girişim için önemli ve gereklidir. Ailesi tarafindan desteklenmeyen bireylerin cesaretinin kırılabileceği, azmindeki sürekliliğin zedelenebileceği ve nihayetinde bir iş kurmaya devam edemeyeceği öngörülmektedir (Carr ve Sequeira, 2007, s. 1093).

Gelecekteki istihdam edilebilirliğe dikkat eden teşvik edici bir aile ortamı, çocuklarda daha yüksek özgüveni, azmi ve kararlılığı teşvik etmektedir. Çocukluk dönemlerinde edinilen yeterlilikler, özgüven, deneyimler ve aşılanan azim istihdamla ilgili becerilerin kazanılmasını ve bu yolla girişimcilik eğilimini güçlendirdiği görülmektedir. Hatta bu durum gelecek girişimler için sosyal ağların geliştirilmesine zemin hazırlamaktadır (Jayawarna vd., 2014, s. 922). Bu nedenle başkaları tarafından sevilmek, kabul görmek ve değer verilmek tehdit sistemlerinin devre dışı bırakılmasını sağlamaktadır. Öz yeterliliğe, iyimserliğe, odaklanmaya, azmetmeye ve özgüvene yol açmaktadır (Matos vd., 2013, s. 150).

Diğer taraftan ebeveynlerin azmi ve cesur davranışları teşvik edip etmemesi çocuğun kararlı ve girişimcilik eğilimini yönlendirmektedir. Çaba yönelimine teşvik edilen bireylerin daha yüksek başarı elde ettikleri görülmektedir. Tersi durumda bağımlı, kararsız, ilgisiz, itaatkâr ve güvensizlik gibi olumsuzluklar yaşanmaktadır (Black, 2014, s. 33). Hatta depresyondaki insanların kendilerini başkalarından daha aşağı gördüğü ve itaatkâr davranışları benimseme eğiliminde olduğu ileri sürülmektedir (Öngen, 2006, s. 794). Bireyin boyun eğme, değersiz ve itaat etme ihtiyacı hissetmesi onun duygusal ve davranışsal özerkliğini, uzun vadeli hedeflere odaklanmasını ve ilgisindeki tutarlılı̆̆ını baltalamaktadır (Öngen, 2006: 799). Çocukluk dönemiyle ilgili utanç yaratan hatıralar bireyin benlik duygularına dokunacağı, başarısızlığını yeşerteceği ve sağlığını tehdit edeceği ileri sürülmektedir (Matos vd., 2013, s. 150).

Öte yandan kontrolcü ebeveynler, kötü davranışı engellemek için yıkıcı eleştiriler ve fiziksel cezalar kullanmaktadır. Bu tarz olumsuz geribildirimler, kişinin kendisinden şüphe ve 
korku yaratmaktadır (Michelle, 2017). Bunlar bireyin davranışlarını, hedeflerini ve azimle çalışmasını olumsuz etkilediği ileri sürülmektedir (Matos vd., 2013, s. 151). Çocukların problem çözme yeteneğini engellemekte, sıkıntı ve kararsızlık yaratarak hareketlerini kısıtlamaktadır (Hong, 2007, s. 287; Matos vd., 2013, s. 152). Bu nedenle ebeveyn kontrolünün sosyal yeterlilik, azim seviyesi ve akran kabulü üzerindeki zararlı etkisinin olduğu ileri sürülmektedir (Ma vd., 2020, s. 11). Literatür ışığında aşağıda belirtilen hipotezler geliştirilmiştir.

H2: Çocukluk deneyimleri azmi anlaml şekilde etkilemektedir.

H2a: Boyun e ğdirici anılar ilgide tutarlılığı anlaml şsekilde etkilemektedir.

H2b: Değersizlik içeren anılar ilgide tutarlılı̆̆ anlaml ş̧ekilde etkilemektedir.

H2c: Tehdit edici anılar ilgide tutarlılı̆̆ anlamlı şekilde etkilemektedir.

H2d: Boyun eğdirici anılar gayrette usrarı anlaml şekilde etkilemektedir.

H2e: Değersizlik içeren anılar gayrette israrı anlaml şekilde etkilemektedir

H2f: Tehdit edici anılar gayrette ssrarı anlamlı şekilde etkilemektedir.

İnsan davranışlarının çoğu hedef yönelimli olmaktadır ve kişinin uzun vadeli hedeflere odaklanması azimle gerçekleşebilmektedir. Girişimciler genellikle iş kurma ve geliştirme aşamasında büyük çabalar harcamakta ve zorlukların üstesinden gelmeye çalışmaktadırlar. $\mathrm{Bu}$ nedenle karşılaştıkları zorluklar anlık değil, uzun yıllar sürebilmektedir. Bu noktada cesaret ve azim gibi özelliklerin girişimcilerde önemli bir başarı kaynağı olabilmektedir. Çünkü insan hayatının önemli bir bölümünü işe adamaktadır ve azim olmadan bunu sürdürebilmesi zordur. Dolayısıyla, bireylerin azim gösterme derecesi girişimci ortamlarda özellikle önemli olabilmektedir. İşin zorluklarının fazla olması sebebiyle; motivasyon, öz denetim ve azim gereklidir (Mueller vd., 2017, s. 260-261).

Yeni bir girişimin başarısına giden yol, sürekli gerilemeler ve başarısızlıklar ile döşenmiştir. Azim, kayıpları soğurmak ve ilerlemek için eşsiz bir unsurdur. Aslında, uzun vadeli hedeflere kararlı bir bağl1lık, özellikle bu hedeflere ulaşmanın zor olduğu durumlarda bile yüksek performans sağlamaktadır (Klein vd., 1999, s. 886; Arco-Tirado vd., 2019, s. 1). Nitekim girişimcilik literatüründe tanımlanan azim, uzun vadeli hedeflere sebat ve tutku ile sürekli çaba gösterme yeteneği şeklinde tanımlanmaktadır (Arco-Tirado vd., 2019, s. 2). Bu nedenle azim, uzun vadede bireylerde özgüven yaratmaktadır (Wolfe ve Patel, 2016, s. 870). Yüksek bir inisiyatif alma düzeyi kazandırmaktadır. Zorluklar karşısında istikrarlı ve 1srarlı olmaya katk1 sağlamaktadır (Schoon ve Duckworth, 2012, s. 1720). Azim, girişimci davranışlarda bulunmak için bireye ilham aşılamaktadır (Sharda, 2019, s. 700). Literatür göz önüne alındığında, azmin girişimcilik niyetini beslediği düşünülmektedir. Dolayısıyla şu hipotezler geliştirilmiştir:

\section{H3: Azim girişimcilik niyetini anlaml şekilde etkilemektedir.}

H3a: Ilgide tutarlılık girişimcilik niyetini anlamlı şekilde etkilemektedir

H3b: Gayrette ısrar girişimcilik niyetini anlamlı şekilde etkilemektedir.

\section{Yöntem}

\subsection{Araştırmanın Evreni ve örneklemi}

Bu çalışma için belirlenen evren olarak 2019-2020 eğitim öğretim yılında Süleyman Demirel (SDÜ) ve Burdur Mehmet Akif Ersoy (MAKÜ) Üniversitelerinin İktisadi ve İdari Bilimler Fakültelerinde öğrenim gören Sağlık Yönetimi Bölümü öğrencileri seçilmiştir. Kümeleme Yöntemi kullanılarak örneklem belirlenmiştir. Buradan yola çıkılarak Sağlık Yönetimi Bölümünün 4. Sınıf öğrencileri örneklem olarak belirlenmiştir. Sağlik yönetimi öğrencilerinin seçilmesinin en önemli sebebi, kamuya istihdam edilmeleri noktasında bölüme özgü kadro tanımlarında sorunların hala devam etmesidir. Bu sorunlardan dolayı girişimcilik niyetine olan eğilimlerinin olup olmaması merak konusudur. Diğer yandan 4. Sınıfların seçilmesindeki amaç ise yakın zamanda eğitim hayatının sonuna gelecek olmaları nedeniyle kariyer planlarını yapmış olabilecekleri düşüncesidir. Bu bağlamda Sağlık Yönetimi Bölümü 
öğrencilerinin girişimcilik niyetlerinin yükselmesi beklenmektedir. Öğrencilerin girişimcilik niyetleri üzerinde çocukluk deneyimlerinin ve azmin etkisinin olup olmadığı ise merak konusudur.

$\mathrm{Bu}$ çalışma için MAKÜ'den 110 ve SDÜ'den de 116 olmak üzere toplam 226 katılımcıdan veri toplanmıştır. Ancak uç değer teşkil etmesi nedeniyle toplam 8 anket analizin dışında tutulmuştur. Geri kalan 218 anketten oluşan veri seti üzerinden analizler gerçekleştirilmiştir.

\subsection{Veri toplama araçları}

Girişimcilik Niyeti Ölçeği: Linan ve Chen (2009) ve tarafindan geliştirilmiş olup tek boyutlu ve 6 maddeden oluşmaktadır. Ölçeğin Türkçe uyarlaması Şeşen ve Basım (2012) tarafından yapılmıştır. Ölçekte (1) Kesinlikle katılmıyorum ve (7) Kesinlikle katılıyorum arasında yedili bir likert derecelendirme kullanılmıştır. Çocukluk Deneyimleri Ölçeği (ÇDÖ): Bu ölçek, Gilbert ve diğerleri (2003) tarafından geliştirilmiştir. ÇDÖ; değersizlik içeren anılar (3 madde), tehdit edici anılar ( 6 madde) ve boyun eğdirici anılar ( 6 madde) olmak üzere 3 boyut ve 15 maddeden oluşmaktadır. Bu ölçek Akın ve diğerleri (2013) tarafından Türkçeye uyarlama çalışması yapılmıştır. Ölçekte, (1) Bana hiç uygun değil ve (5) Bana tamamen uygun şeklinde beşli bir likert kullanılmıştır. Kısa Azim Ölçeği: Duckworth ve Quinn (2009) tarafından geliştirilmiş olan bu ölçek; ilgide tutarlılık (4 madde) ve gayrette 1srar (4 madde) olmak üzere 2 boyut ve 8 maddeden oluşmaktadır. Ölçeğin Türkçe uyarlaması ve dil eşdeğerliliği ise Sarıçam ve diğerleri (2016) tarafından yapılmıştır. Ölçek; (1) Hiç bana göre değil ve (5) Tam bana göre olmak üzere beşli bir likert derecelendirme kullanılmıştır.

Ölçeklerin faktör yapılarını test etmek amacıyla AMOS 23 Programı kullanılarak Doğrulayıcı Faktör Analizi (DFA) yapılmıştır. Tüm değişkenlerin normal dağılım değerlerinin (çarpıklık ve basıklık) -1 ve +1 arasında (Gürbüz ve Şahin, 2015:208-210) olduğu tespit edilmiş olup veri setinin normal dağılım gösterdiği saptanmıştır. Bu nedenle Maximum Likelihood hesaplama yöntemi kullanılmıştır. Modelin uyumluluğunu değerlendirmek için dikkate alınması gereken bazı uyum endeksleri gösterilmiştir.

İlk etapta Girişimcilik Niyeti Ölçeğine tek faktörlü DFA analizi uygulanmıştır. Elde edilen bulgular sonucunda uyum iyiliği değerlerinin modifikasyona ihtiyacının olduğu tespit edilmiştir. Bu noktada $\mathrm{G} 1 \leftrightarrow \mathrm{G} 2$ ve $\mathrm{G} 4 \leftrightarrow \mathrm{G} 6$ maddeleri arasında modifikasyon işlemi yapılarak birbirine bağlanmıştır. Üç faktörlü Çocukluk Deneyimleri Ölçeğine birinci düzey çok faktörlü DFA analizi uygulanmış ve uyum iyiliği değerlerinin yazın dünyasında kabul edilen düzeyde olmadığı tespit edilmiştir. Bu nedenle gerekli modifikasyon işlemlerinin uygulanması neticesinde Boyun Eğdirici Anılar boyutuna ait B4↔B6 maddeleri arasında modifikasyon işlemi uygulanarak birbirine bağlanmıştır. Aynı ölçeğin ikinci düzey DFA analizi yapıldığında da aynı modifikasyon uygulanmıştır. İki faktörlü Kısa Azim Ölçeğinin de hem birinci hem de ikinci düzey çok faktörlü DFA analizleri neticesinde benzer modifikasyon işlemleri uygulanarak İlginin Tutarlılı̆ 1 boyutunun IT $1 \leftrightarrow \mathrm{IT} 2$ maddeleri birbirine bağlanmıştır. DFA analizleriyle ilgili elde edilen uyum iyiliği değerleri de Tablo 1'de gösterilmiştir. Ancak yazın dünyasında hangi uyum iyiliği değerlerinin daha güvenilir ve makbul görüldüğüne ilişkin tam bir uzlaşma bulunmamaktadır. Fakat hem güncel çalışmalarda hem de Monte Carlo çalışmalarında genel olarak; $X^{2}$ ve bunun $p$ değeri, $\mathrm{X}^{2} / \mathrm{df}$, GFI, CFI, SRMR ve RMSEA değerlerinin raporlandığı görülmektedir (Gürbüz, 2019, s. 36; Braun Santos vd., 2016, s. 137; Tarhini vd., 2016: 1275). Bu çalışmada da söz konusu bu değerler raporlanmıştır (Bkz. Tablo 1). 
Tablo 1. Doğrulayıcı faktör analizi modellerine ilişkin uyum iyiliği değerleri

\begin{tabular}{|c|c|c|c|c|c|c|c|c|}
\hline & $X^{2}$ & $\mathrm{df}$ & $p$ & $\mathrm{X}^{2} / \mathrm{df}$ & GFI & CFI & $\begin{array}{c}\text { SRM } \\
\text { R }\end{array}$ & $\begin{array}{c}\text { RMSE } \\
\text { A }\end{array}$ \\
\hline $\begin{array}{l}\text { Kabul Edilebilir } \\
\text { Değerler }\end{array}$ & & & $\mathrm{p} \leq .05$ & $\begin{array}{c}3 \leq \chi^{2} / \mathrm{sd} \leq \\
5\end{array}$ & $\begin{array}{l}\text { GFI } \\
\geq .90\end{array}$ & $\begin{array}{c}\mathrm{CFI} \geq .9 \\
0\end{array}$ & $\begin{array}{c}\mathrm{SRM} \\
\mathrm{R} \leq .08 \\
\end{array}$ & $\begin{array}{l}\text { RMSE } \\
\mathrm{A} \leq .08\end{array}$ \\
\hline Girişimcilik Niyeti & 14.12 & 7 & .04 & 2.02 & .98 & .99 & .02 & .07 \\
\hline${ }^{\mathrm{a} C ̧ o c u k l u k ~ D e n e y i m l e r i ~}$ & 161.05 & 86 & .00 & 1.87 & .90 & .94 & .05 & .06 \\
\hline${ }^{\mathrm{a} A z i m}$ & 35.03 & 18 & .00 & 1.95 & .96 & .95 & .05 & .07 \\
\hline${ }^{\mathrm{b} C}$ Cocukluk Deneyimleri & 161.05 & 86 & .00 & 1.87 & .90 & .94 & .05 & .06 \\
\hline bAzim & 35.03 & 18 & .00 & 1.95 & .96 & .95 & .05 & .07 \\
\hline
\end{tabular}

Tablo 1'de verilen bulgulara göre, ölçeklerin hem tek faktörlü hem de çok faktörlü model yapıları veriler ile uyumlu ve kabul edilebilir düzeydedir. Yapılan DFA analizleri uyum iyiliği değerlerinin yazında kabul edilen değerlere uygun olduğu bulunmuştur. Dolayısıyla ölçeklerin kuramsal yapılarının doğrulandığı ifade edilebilir.

DFA analizlerinden sonra değişkenlerin güvenirlik değerleri incelenmiş ve analizlerde esas olarak kullanılacak olan örtük değişkenler oluşturulmuştur. Buna göre tüm değişkenlerin en az iyi düzeyde Cronbach's Alpha güvenirlik katsayısına sahip olduğu tespit edilmiştir. Değişkenlerin elde edilen bu sonuçları Tablo 4'te gösterilmiştir.

\section{Bulgular}

Araştırmanın bu bölümünde katılımcıların sosyo-demografik bilgileri, cinsiyet bağlamında değişkenlerin ortalamaları arasındaki farklılıkları, değişkenler arasındaki korelasyon ve regresyon testi bulguları sunulmuştur.

Tablo 2. Katılımc1ların sosyo-demografik özellikleri

\begin{tabular}{|c|c|c|c|c|c|c|c|}
\hline & & $\mathrm{N}$ & $\%$ & & & $\mathrm{~N}$ & $\%$ \\
\hline \multirow{3}{*}{ Cinsiyet Dağılımı } & Kadın & 150 & 68.8 & Ailenin & $\leq 2500$ & 90 & 41.7 \\
\hline & Erkek & 68 & 31.2 & Ortalama & $2501-4500$ & 85 & 39.4 \\
\hline & & & & Aylik & $4501-6500$ & 32 & 14.8 \\
\hline \multirow{2}{*}{ Yaş Dağıllımı } & 21 & 45 & 20.6 & Geliri & $\geq 6501$ & 9 & 4.2 \\
\hline & 22 & $\begin{array}{l}90 \\
83\end{array}$ & $\begin{array}{l}41.3 \\
381\end{array}$ & Üniversite & $\begin{array}{l}\text { MAKU } \\
\text { SDÜ }\end{array}$ & 103 & $\begin{array}{l}41.2 \\
528\end{array}$ \\
\hline
\end{tabular}

Tablo 2'de gösterilen sosyo-demografik bulgulara göre katılımcıların çoğu kadın katılımcılardan oluşmaktadır. 22 yaşına olanlar çoğunluktadır. Yine ortalama aylık gelirinin 2500 TL ve altı olan aileler birinci sirada iken, 2501-4500 TL aralığında olanların ise ikinci sirada olduğu görülmektedir. Katılımcıların mensubu olduğu üniversite açısından değerlendirildiğinde ise nerdeyse eşit dağılım gösterdiği söylenebilir.

Katılımcıların demografik özellikleri bağlamında; çocukluk deneyimleri, azim ve girişimcilik niyeti ortalamalarında farklılığın olup olmadığını tespit etmek amacıyla Independent Sample T Test ve ANOVA Testi uygulanmıştır. Yaş grupları ve ailenin ortalama geliri bağlamında ölçeklerin ve ilgili boyutlarının ortalamalarında anlamlı bir farklılığa rastlanmamıştır ( $>$ >.05). Dolayısıyla bu bulgulara ilişkin bir tablo verilmemiştir. Ancak girişimcilik niyeti ortalamalarında, cinsiyet değişkeni bağlamında anlamlı bir farklık tespit edilmiştir. Elde edilen bulgular ise Tablo 3’te gösterilmiştir. 
Tablo 3. Cinsiyet bağlamında fark analizi tablosu

\begin{tabular}{lcccccccc}
\hline & \multicolumn{1}{c}{ Kadın } & \multicolumn{1}{c}{ Erkek } & \\
\cline { 2 - 9 } & $\overline{\mathrm{X}}$ & $\mathrm{SS}$ & $\overline{\mathrm{X}}$ & $\mathrm{SS}$ & $\mathrm{p}$ & $\mathrm{t}$ & $\mathrm{f}$ & Anlamlı Fark \\
\hline Girişimcilik Niyeti & 3.27 & 1.02 & 3.65 & 1.04 & .01 & -2.52 & .51 & Erkek $>$ Kadın \\
\hline D.f. $($ Serbestlik Derecesi $)=216$ & & & & & & & & \\
\hline
\end{tabular}

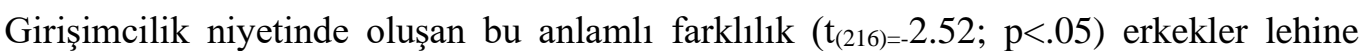
olduğu tespit edilmiştir. Kadın katılımcı sayısının erkeklere nazaran daha fazla olmasına rağmen girişimcilik niyetine ilişkin erkeklerin ortalamasının $(\overline{\mathrm{X}}=3.65 ; \quad \mathrm{S} . \mathrm{S} .=1.04)$ kadınların ortalamasından $(\overline{\mathrm{X}}=3.27 ; \mathrm{S} . \mathrm{S} .=1.02)$ daha yüksek olduğu tespit edilmiştir.

Değişkenler arasındaki ilişkinin anlamlı olup olmadığını ortaya koymak ve bu ilişkilerinin yönünü ve şiddetini belirlemek amacıyla korelasyon analizi uygulanmıştır. Bu ilişki aynı zamanda değişkenler arasında etkinin de olabileceğine işaret etmektedir. Korelasyon analizi sonucunda elde edilen bulgular, değişkenlerin ortalamaları ve güvenirlik değerleri Tablo 4'te gösterilmiştir.

Tablo 4. Korelasyon, ortalamalar ve güvenirlik değerleri tablosu

\begin{tabular}{|c|c|c|c|c|c|c|c|c|c|c|}
\hline & $\bar{X}$ & $S S$ & 1 & 2 & 3 & 4 & 5 & 6 & 7 & 8 \\
\hline 1. Ç.D. & 2.17 & .70 & $(.888)$ & & & & & & & \\
\hline 2. B.E.A. & 2.33 & .83 & $.899 * *$ & $(.808)$ & & & & & & \\
\hline 3. D.E.A. & 2.08 & .82 & $.665^{* *}$ & $.443 * *$ & (.619) & & & & & \\
\hline 4. T.E.A. & 2.05 & .82 & $.906 * *$ & $.698 * *$ & $.480 * *$ & $(.829)$ & & & & \\
\hline 5. Azim & 3.43 & .55 & $-.280 * *$ & $-.274 * *$ & -.086 & $-.281 * *$ & $(.691)$ & & & \\
\hline 6. İ.T. & 3.02 & .79 & $-.258 * *$ & $-.263 * *$ & -.025 & $-.275^{* *}$ & $.823 * *$ & $(.710)$ & & \\
\hline 7. G.I. & 3.84 & .63 & $-.164^{*}$ & $-.147^{*}$ & -.118 & $-.145^{*}$ & $.706 * *$ & $.180^{* *}$ & $(.720)$ & \\
\hline 8. G.N. & 3.39 & 1.04 & -.014 & .011 & -.123 & .019 & $.219 * *$ & .108 & $.246 * *$ & $(.933)$ \\
\hline $\begin{array}{l}* * p<.01, \\
\text { Cronbach } \\
\text { C.D.: Çoc } \\
\text { B.E.A.: Bo } \\
\text { D.E.A.: D } \\
\text { T.E.A.: Te } \\
\text { I.T.: Ilgini } \\
\text { G.I: Gayr } \\
\text { G.N: Giri }\end{array}$ & $\begin{array}{l}0<.0 \\
\text { Alpha } \\
\text { uk De } \\
n \text { E } \breve{g} \\
\text { ersizli } \\
\text { it Edic } \\
\text { Tutarl } \\
\text { Israr } \\
\text { cilik }\end{array}$ & $\begin{array}{l}\text { mleri } \\
\text { Anila } \\
\text { ren Ar } \\
\text { ilar }\end{array}$ & erleri & tez iç & ve kc & intola & gösteri & & & \\
\hline
\end{tabular}

Tablo 4'te gösterilen bulgulara göre çocukluk deneyimleri ve ilgili tüm boyutlarının girişimcilik niyetiyle anlamlı bir ilişkisinin olmadığ 1 ( $>.05$ ), ancak azmin ve ilgili boyutlarından olan gayrette 1srar ise girişimcilik niyetiyle anlamlı ve olumlu bir ilişkisini olduğu tespit edilmiştir $(\mathrm{p}<.01)$. Diğer yandan çocukluk deneyimleri ve ilgili boyutlarından olan boyun eğdirici anılar ve tehdit edici anıların, azim ve ilgili boyutlarıyla anlamlı ancak negatif yönlü bir ilişkisinin olduğu görülmektedir $(\mathrm{p}<.05)$.

Korelasyon analizi sonrasında bağımsız değişkenlerin bağımlı değişkenler üzerindeki etkilerini tespit etmek amacıyla doğrusal regresyon analizi uygulanmıştır. Burada bağımsız bir değişken olarak çocukluk deneyimlerinin, azim ve girişimcilik niyeti bağımlı değişkenlerine etkisi araştırılmıştır. Bunun yanında bağımsız değişken rolündeki azmin bağımlı değişken olarak belirlenen girişimcilik niyetine etkisi tespit edilmeye çalışılmıştır. Regresyon analizi sonucunda ulaşılan bulgular da Tablo 5 'te gösterilmiştir. 
Tablo 5. Regresyon testi bulguları

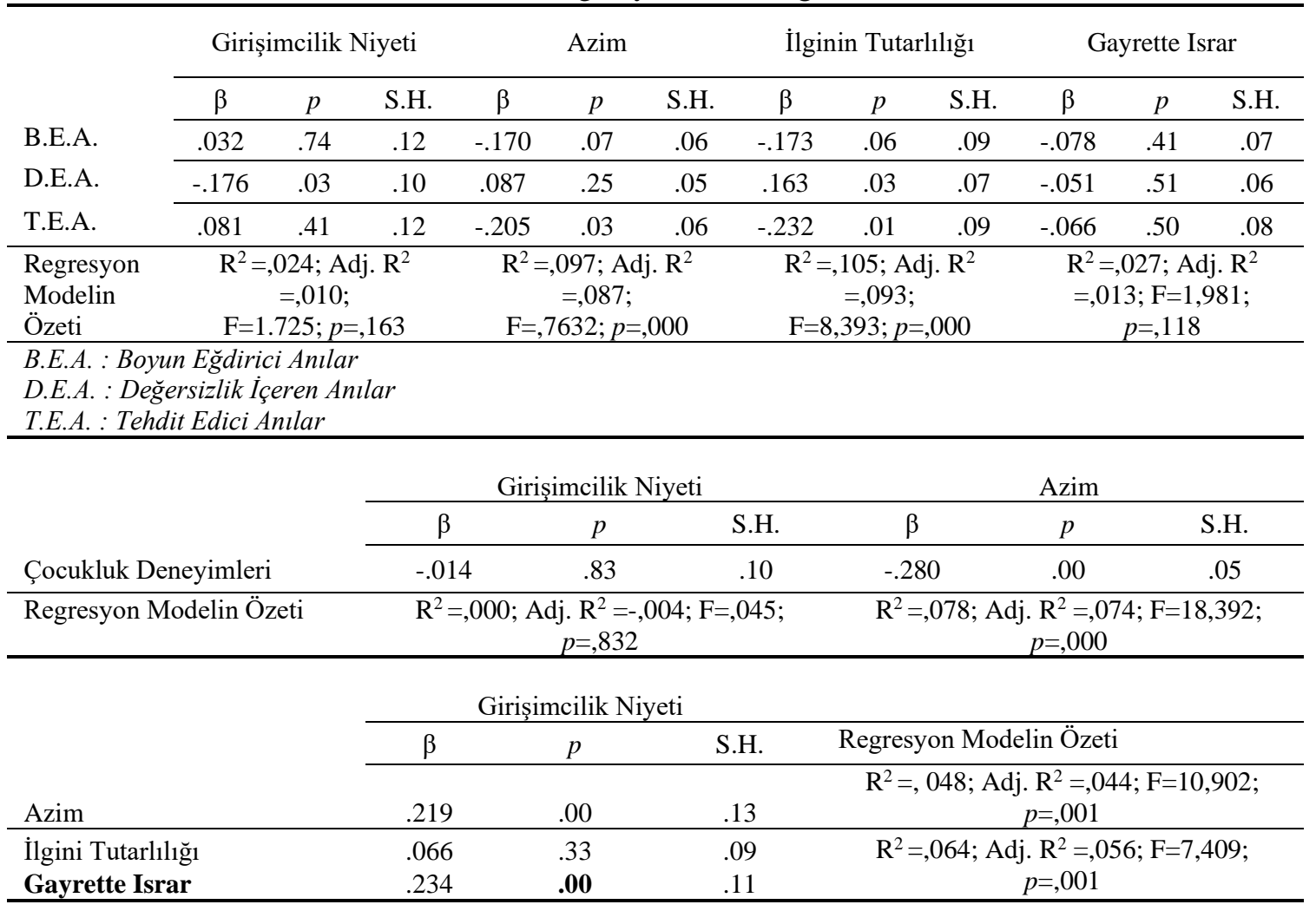

Tablo 5, üç bölümden oluşmaktadır. Her bir bölüm kalın punto çizgilerle ayrılmıştır. Buna göre ilk bölümde çocukluk deneyimleri ölçeği ve boyutlarının, azim ölçeği ve ilgili boyutları ile girişimcilik niyeti üzerindeki etkisi incelenmiştir. Buna göre değersizlik içeren anıların girişimcilik niyeti $(\beta=-, 176 ; p<0.05)$ üzerinde negatif ve ilginin tutarlılığı $(\beta=, 163$; $\mathrm{p}<0.05)$ üzerinde ise pozitif bir etkisinin olduğu tespit edilmiştir. Tehdit edici anıların ise sadece azim $(\beta=-, 205 ; p<0.05)$ ve ilginin tutarlılığg $(\beta=-, 232 ; p<0.05)$ değişkenleri üzerinde anlamlı ve negatif bir etkisinin olduğu görülmektedir.

Tablonun ikinci aşamasında, bir bütün olarak çocukluk deneyimlerinin bir bütün olarak azim değişkeni ve girişimcilik niyeti üzerindeki etkisine ilişkin bulgular gösterilmiştir. Burada çocukluk deneyimlerini girişimcilik niyetini anlamlı şekilde etkilemezken ( $\mathrm{p}>.05)$, azim üzerinde anlamlı ve negatif bir etkisinin olduğu tespit edilmiştir $(\beta=-, 280 ; p<0.05)$.

Tablonun son kısmında ise bir bütün olarak azim değişkenin girişimcilik niyetini ( $\beta=, 219$; $\mathrm{p}<.05$ ) anlamlı ve olumlu şekilde yordadığ 1 görülmektedir. Boyutların etkisi incelendiğinde ise sadece gayrette 1srar boyutunun girişimcilik niyetini anlamlı ve olumlu etkilediği tespit edilmiştir $(\beta=, 234 ; p<0.05)$.

Yapılan analiz sonuçlardan hareketle $\mathrm{H} 1 \mathrm{~b}, \mathrm{H} 2, \mathrm{H} 2 \mathrm{~b}, \mathrm{H} 2 \mathrm{c}, \mathrm{H} 3$ ve $\mathrm{H} 3 \mathrm{~b}$ hipotezleri desteklenmiştir. H1, H1a, H1c, H2, H2a, H2d, H2e, H2f ve H3a hipotezleri ise reddedilmiştir.

\section{Tartışma ve Sonuç}

Girişimcilik eğiliminin geliştirilmesine yönelik yapılan araştırmalar, yüzyılın küresel sorunlarını aşmak için girişimci yeteneklerinin kilidini açacağı ve sonraki girişimci neslin yetiştirilmesinde katkılar sağlayacağı düşünülmektedir (Obschonka vd., 2017, s. 488). Benzer bir katkı sunması amacıyla tasarlanan bu çalışma da; çocukluk deneyimlerinin, girişimcilik niyeti ve azim gibi önemli unsurlar arasındaki ilişkiyi ortaya koymayı amaçlamaktadır. Başta çocukluk 
deneyimlerinin azim ve girişimcilik niyetine etkisi test edilmiştir. Ardından azmin girişimcilik niyetini üzerindeki muhtemel etkisi ortaya konulmaya çalışılmıştır.

Yapılan analiz sonucunda çocukluk deneyimlerinin boyutlarından olan değersizlik içeren anıların girişimciliği düşürdüğü tespit edilmiştir. Nitekim girişimcilik niyeti üzerinde ailenin etkisinin olduğu ileri sürülmektedir. Bu etki aynı zamanda gelecekteki beşeri sermayesinin geliştirilmesi açısından çok güçlü olduğu tespit edilmiştir (Jayawarna vd., 2014, s. 936). Fakat bu etkinin her toplumda gerçekleşmesi de söz konusu değildir. Kolektivist toplumlarda büyüyen bireyler, kendilerini başkalarıyla yakından ilişkili olarak görmeye daha eğilimlidirler ve bireylerin benlik kavramı, öncelikle kendi gruplarındaki diğer insanlarla olan ilişkilere dayalı olarak tanımlanma eğilimindedir (Ma vd., 2020, s. 3). Özellikle ataerkil bir toplumda anne ve babanın denetim ve itaat bekleme düzeyleri daha yüksek olmaktadır. Bu sebeple Türkiye gibi toplulukçu toplumlarda ebeveynler genellikle gençlerin olgun ve itaatkâr olmalarını beklemektedirler (Shek, 2007, s. 125). Otoritenin hâkim olduğu ailelerde de girişimciliği ve özgür hareket etme eğilimini baltalayan bir yönünün olduğu söylenebilir. Ohe ve Ohe (1996; Akt: Drennan vd., 2005, s. 239) zor bir çocukluğun girişimcilik algısı için önemini ortaya koymuşlardır. Ailenin bağımsızlık ve özerklik duygusunu geliştiren tutum ve davranışlarda bulunması çocuklarda içsel kontrol odağını geliştirip girişimci yönünü desteklerken, korumacı ve kontrol etme yanlısı davranışları da çocukların bağımlı ve dışsal kontrol odağının gelişmesine yol açmaktadır. Kümbül Güler (2008, s. 24), bu durumun girişimcilik eğilimini de olumsuz etkileyeceğini ileri sürmektedir. $\mathrm{Bu}$ çalışmada ise çocukluk deneyimleri ve ilgili boyutları olan boyun eğdirici ve tehdit edici anıların girişimciliği anlamlı etkilemediği tespit edilmiştir. Nitekim Rachmawan ve diğerleri (2015: 427) girişimcilik niyetinin ebeveynlerin etkisi dışında gelişebileceğinin istisnai bir durum olduğunu ifade etmektedirler.

Algılanan aile destek eksikliği nedeniyle çocukların cesaretleri kırılabilir (Carr ve Sequeira, 2007, s. 1096). Ancak ebeveynlerin rol model olarak veya destek sağlayarak (Naktiyok ve Timuroğlu, 2009, s. 92) çocuklar üzerindeki kontrol düzeyini düşürmesi öz yeterlilik kazanmaları açısından önem arz etmektedir. Çünkü algılanan aile desteği, öz yeterliliği olumlu etkilerken (Carr ve Sequeira, 2007, s. 1094), öz yeterliliğin de girişimcilik niyetini pozitif anlamda etkilediği görülmektedir (Önay vd., 2017, s. 55; Farrukh vd., 2017, s. 310). Ebeveynleri aracılığıyla eriştikleri daha güçlü ve önemli sosyal ağlara sahip gençler, girişimciliğe daha fazla ilgi duymaktadır (Jagannathan, vd., 2017, s. 16). Ayrıca aileden görülen destek salt bir destek ve cesaret vermekle kalmayıp, aynı zamanda ebeveynlerin beklentilerini gerçekleştirme motivasyonu da sağlamaktadır (Vela vd., 2015, s. 290).

Bir bütün olarak çocukluk deneyimleri ve ilgili boyutu olan tehdit edici anıların, azmi olumsuz etkilediği görülmektedir. Diğer yandan tehdit edici anılar azmin ilgide tutarlılık boyutunu da olumsuz şekilde yordadığı saptanmıştır. Değersizlik içeren, tehdit edici ve boyun eğdirici anıların kendini sevme ve öz yeterlilikle olumsuz ilişkisi bulunmaktadır. Aynı zamanda bunları negatif bir şekilde yordadığ tespit edilmiştir (Taner, 2019, s. 56-58). Boyun eğdirici ve tehdit edici anıların anksiyete, depresyon ve stres üzerinde anlamlı ve arttırıcı bir etkiye sahip olduğu ileri sürülmektedir (Richter vd., 2009, s. 179). Bu durum şüphesiz azim gibi öz yeterlilik inanc1 gerektiren bir unsuru da olumsuz etkileyecektir. Nitekim çocukların boyun eğdirici davranışları ile güven arasında olumsuz bir ilişki bulunmaktadır (Irons ve Gilbert, 2005, s. 332).

Diğer yandan değersizlik içeren anılar azmin ilgide tutarlılık boyutunu olumlu şekilde yordadığı saptanmıştır. Olumsuz çocukluk deneyimleri bazen daha sonraki zorluklarla başa çıkmak için gerekli ve yararlı bir önkoşul olabilmektedir. Çocuğun yetişkinlikteki öz yeterliliğini geliştirebilmektedir (Cox ve Jennings, 1995, s. 5). Bu durumun kültürle açıklanabileceği ileri sürülmektedir. Toplulukçu toplumlarda ebeveynlerin kontrolü kısmen daha sıkı ve çocuklar daha fazla itaat edilebilmektedir. Bu kontrol çocuğu pasifleştirmekte, kendine olan güveni azaltmakta ve değersizlik hissine yol açmaktadır (Ma vd., 2020, s. 2). Türkiye'de toplulukçu bir kültüre mensup olup böyle bir etkinin varlığı söz konusu olduğu ifade edilmektedir (Yener, 2018, s. 872). 
Bazı olumsuz çocukluk yaşantıları dayanıklılığı, başa çıkma ve problem çözme yeteneklerini geliştirebildiği ileri sürülmektedir (Hong, 2007, s. 283).

Ebeveynlerin sıkı kontrolü, çocukları onay almaya daha fazla zorlamaktadır. Bu stresörler altında, yüksek ebeveyn kontrolü, arzu edilemeyen baskı, ihmal ve itaat beklentisi öğrencilerin motivasyonlarını azaltabilmektedir (Ma vd., 2020, s.8). Çocukluk deneyimlerinde ihmal edilme, terk edilme, istismar, değersiz görülme gibi utanç anılarının depresyonla (Matos vd., 2013, s. 155) ve stres ve ilgisizlikle olumlu bir ilişkisi tespit edilmiştir. Böyle ortamlar yetişkinlikte psikolojik bozukluğa ve uyumsuzluğa yol açtığı ileri sürülmektedir (Irons vd., 2006, s. 297 ;Matos vd., 2013, s. 149; Richter vd., 2009, s. 179; Gouveia vd., 2016, s.54). Psikolojik sorunlarla mücadele ederken azim ile uzun vadeli hedeflere odaklanmak mümkün görülmemektedir.

Bir bütün olarak azim ve azmin boyutu olan gayrette israr girişimcilik niyetini pozitif şekilde etkilerken ilginin tutarlılığ ise anlamlı etkilememektedir. Bu, beklenen bir sonuçtur. Çünkü girişimcilik gibi yıllar süren bir mücadelede azimli olmak, işine aşk ve tutkuyla bağlanarak gayrette ısrar etmek başarının anahtarıdır. Bu sonucu destekleyen önemli çalışmalar da literatürde mevcuttur. Butz ve diğerleri (2018, s. 10-12), azim ve girişimcilik niyeti arasında yüksek düzeyde anlamlı ve olumlu bir ilişki tespit etmiş̧lerdir. Ayrıca girişimciliğin; sebat etme (Cardon ve Kirk, 2015, s. 1039), performans (Mueller vd., 2017, s. 260), başarı ihtiyacı, kontrol odağ 1 , öz yeterlilik ve riske tolerans (Nejat ve Basım, 2012, s. 25; Arco-Tirado vd., 2019, s. 6), kendini geliştirme ve değişime açıklık kültürel değerleri (Naktiyok ve Timuroğlu, 2009, s. 95-96), kişilik ve özgüven (Obschonka vd., 2017, s. 495) gibi unsurlarla anlamlı ve olumlu ilişkisi tespit edilmiştir. Azmin gayrette 1srar bileşeninde daha yüksek olduğunu bildiren öğrencilerin verimliliğinin daha yüksek olduğu ileri sürülmektedir (Hodge vd., 2018, s. 457). Azmin üretkenlik ve tutkunluğu yükseltmekte olduğu ve bu durumun cinsiyet bağlamında farklılık göstermediği görülmektedir (Hodge vd., 2018, s. 455).

$\mathrm{Bu}$ çalışmanın önemli bir diğer sonucu ise erkeklerin kadınlara oranla girişimcilik niyetlerinin daha yüksek olmasıdır. Bu sonuç Geldhof ve diğerlerinin $(2014$, s. 84) çalışma bulgularını desteklemektedir. Öyle ki zaten erkeklerin girişimciliğe daha fazla eğilimli olduğuna inanılmaktadır. Ancak girişimcilik niyetlerinde cinsiyet farklılıkları bulunsa bile, bunun kültüre duyarlı bir durum olduğu ileri sürülmektedir (Jagannathan vd., 2017, s. 4). Kadınların girişimci özelliklerinin olup olmaması, ailenin sosyoekonomik kaynaklarına erişiminin erkeklerden daha yüksek olmasıyla ilişkilendirilmiştir. Bu durum, kendi işlerini kurup kurmayacakları üzerinde doğrudan bir etkiye sahip olduğu ifade edilmektedir (Schoon ve Duckworth, 2012, s. 1722).

\section{Öneriler}

Araştırmacılar için öneriler: Mevcut araştırmalar, girişimcilik niyeti gelişiminin birden fazla kişisel ve bağlamsal faktörün dinamik etkileşimi yoluyla gerçekleştiğini göstermektedir. Bu nedenle, çalışmanın bu bulguları sadece çocukluk deneyimleri ve azmin girişimcilik niyetine etkisini araştırarak büyük bir buzdağının sadece küçük bir ipucunu temsil etmektedir. Buradan hareketle gelecekteki araştırmalar, girişimci bir tutumun gelişiminin nelerden etkilenebileceğini daha iyi anlamak için zor çocukluğun diğer yönlerini derinlemesine inceleyebilir. Bu tür araştırmaların, bireylerin daha girişken olmasına yol açan belirli niteliklerin geliştirilmesine iliş̧kin katkı sağlaması beklenmektedir. Yanı sıra önceden iş kurma niyeti olanların, niyetlerinin gerçekten eyleme geçip geçmediğini belirlemek için boylamsal çalışmalar da gereklidir. Çünkü bireyler iş kurma konusunda güçlü olumlu tutumlar sergileyebilir ve yüksek öz-yeterliliğe sahip olabilirler. Ancak niyetler her zaman davranışa dönüşmeyebilir. Bu durum, bireylerin girişimcilik faaliyetlerine başlamasını engelleyen faktörlerin bilinmesi açısından, girişimcilik sürecine ek bir bakış açısı getireceği düşünülmektedir.

Uygulayıcılar için öneriler; Kariyer seçimi olarak girişimciliğe ilginin artması isteniyorsa, çocuklar erken dönemde teşvik edilmeli ve azimli olmaları gerektiğinin önemi vurgulanmalıdır. Erken çocukluk döneminde bilişsel uyarım ve yaratıcı yeteneklerin teşvik edilmesi, yetişkinlikte girişimci kariyer için önemli belirleyiciler olabilir. Bu noktada, çocuklara hedef belirleme 
stratejilerinin öğretilmesi gerekmektedir. Azimle, uzun vadeli bir hedefe yönelik kararlılığının altı çizilmelidir. Bu nedenle, iyi hedefler koymayı öğretmek, çocukların azmini geliştirmenin ilk adımıdır. $\mathrm{Bu}$ öncelikle çocukların akademik davranışları hakkında ayrıntılı geri bildirim sağlayarak yapılmalıdır. Buradaki amaç öğrencilere performansın uygulama ile gelişebileceğini göstermektir. Ayrıca çocuklara gücü ölçüsünde sorumluluk vermek öz yeterliliğini, kendine güveninin ve başarı hazzını deneyimlemesine zemin hazırlamaktadır. Dolayısıyla çocuklara algılanan kontrolün kendilerinde olduğu hissinin verilmesi gerekmektedir. Bu durumun çocuğun girişimci, atılgan ve azimli olmasında etkisinin yüksek olacağı düşünülmektedir.

\section{Kaynakça}

Ajzen, I. (2002). Residual effects of past on later behavior: Habituation and reasoned action perspectives. Personality and Social Psychology Review, 6(2), 107-122.

Akın, A., Uysal, R. ve Nihan, Ç. (2013). Çocukluk deneyimleri ölçeğinin Türkçeye uyarlanması. Sakarya Üniversitesi, Kastamonu Eğitim Dergisi, 21(4), 1541-1550.

Aldrich, H. ve Cliff, J. (2003). The pervasive effects of family on entrepreneurship: toward a family embeddedness perspective. Journal of Business Venturing, 18(5), 573-596.

Arco-Tirado, J. L., Bojica, A., Fernández-Martín, F. ve Hoyle, R. H. (2019). Grit as predictor of entrepreneurship and self-employment in Spain. Frontiers in Psychology, 10, 389-389.

Aytaç, Ö. ve İlhan, S. (2007). Girişimcilik ve girişimci kültür: sosyolojik bir perspektif. Selçuk Üniversitesi Sosyal Bilimler Enstitüsü Dergisi, 18, 101-120.

Black, K. R. (2014). Grit in college students: Associations with achievement and parental influences. Graduate Theses, Dissertations, and Problem Reports. DOI:https://doi.org/10.33915/etd.5218.

Braun Santos, D., Mendes-Da-Silva, W., Flores, E. ve Norvilitis, J. M. (2016). Predictors of credit card use and perceived financial well-being in female college students: a B razil-U nited S tates comparative study. International journal of consumer studies, 40(2), 133-142.

Bullough, A., Renko, M. ve Myatt, T. (2014). Danger zone entrepreneurs: the importance of resilience and self-efficacy for entrepreneurial intentions. Entrepreneurship Theory and Practice, 38(3), 473-499.

Butz, N. T., Hanson, S., Schultz, P. L. ve Warzynski, M. M. (2018). Beyond the Big Five: does grit influence the entrepreneurial intent of university students in the US?. Journal of Global Entrepreneurship Research, 8(1), 1-16.

Cardon, M. S. ve Kirk, C. P. (2015). Entrepreneurial passion as mediator of the self-efficacy to persistence relationship. Entrepreneurship Theory and Practice, 39(5), 1027-1050.

Carr, J. C. ve Sequeira, J. M. (2007). Prior family business exposure as intergenerational influence and entrepreneurial intent: A theory of planned behavior approach. Journal Of Business Research, 60(10), 1090-1098.

Chaudhary, R. (2017). Demographic factors, personality and entrepreneurial inclination. Education + Training, 59(2), 171-187.

Collins, O. F. ve Moore, D. G. (1964). The enterprising man, East Lansing: Michigan State University. 
Cox, C. ve Jennings, R. (1995). The foundations of success: the development and characteristics of British entrepreneurs and intrapreneurs. Leadership and Organization Development Journal, 16(7), 4-9.

Çelik, İ. ve Sarıçam, H. (2018). The relationships between academic locus of control, positive thinking skills and grit in high school students. Universal Journal of Educational Research, $6(3), 582-585$.

Drennan, J., Kennedy, J. ve Renfrow, P. (2005). Impact of childhood experiences on the development of entrepreneurial intentions. The International Journal of Entrepreneurship and Innovation, 6(4), 231-238.

Duckworth, A. L., Peterson, C., Matthews, M. D. ve Kelly, D. R. (2007). Grit: Perseverance and passion for long-term goals. Journal of Personality and Social Psychology, 92(6), 1087-1101.

Farrukh, M., Khan, A. A., Khan, M. S., Ramzani, S. R. ve Soladoye, B. S. A. (2017). Entrepreneurial intentions: the role of family factors, personality traits and selfefficacy. World Journal of Entrepreneurship, Management and Sustainable Development, 13(4), 303-317

Geldhof, G. J., Weiner, M., Agans, J. P., Mueller, M. K. ve Lerner, R. M. (2014). Understanding entrepreneurial intent in late adolescence: The role of intentional self-regulation and innovation. Journal of Youth and Adolescence, 43(1), 81-91.

Gilbert, P., Cheung, M. S. P., Grandfield, T., Campey, F. ve Irons, C. (2003). Recall of threat and submissiveness in childhood: Development of a new scale and its relationship with depression, social comparison and shame. Clinical Psychology \& Psychotherapy: An International Journal of Theory \& Practice, 10(2), 108-115.

Gouveia, J. P., Xavier, A. ve Cunha, M. (2016). Assessing early memories of threat and subordination: Confirmatory Factor Analysis of the Early Life Experiences Scale for adolescents. Journal of Child and Family Studies, 25(1), 54-64.

Gürbüz, S. (2019). AMOS ile yapısal eşitlik modellemesi temel ilkeler ve uygulamalı analizler. Ankara: Seçkin Yayıncılık.

Gürbüz, S. ve Şahin F. (2015), Sosyal bilimlerde araştırma yöntemler., Ankara: Seçkin Yayıncilik.

Hill, P. L., Burrow, A. L. ve Bronk, K. C. (2016). Persevering with positivity and purpose: An examination of purpose commitment and positive affect as predictors of grit. Journal of Happiness Studies, 17(1), 257-269.

Hodge, B., Wright, B. ve Bennett, P. (2018). The role of grit in determining engagement and academic outcomes for university students. Research in Higher Education, 59(4), 448-460.

Hong, R. Y. (2007). Worry and rumination: Differential associations with anxious and depressive symptoms and coping behavior. Behaviour Research and Therapy, 45(2), 277-290.

Irons, C. ve Gilbert, P. (2005). Evolved mechanisms in adolescent anxiety and depression symptoms: The role of the attachment and social rank systems. Journal of adolescence, 28(3), 325-341.

Irons, C., Gilbert, P., Baldwin, M. W., Baccus, J. R. ve Palmer, M. (2006). Parental recall, attachment relating and self-attacking/self-reassurance: Their relationship with depression. British Journal of Clinical Psychology, 45(3), 297-308. 
Jagannathan, R., Camasso, M. J., Das, B., Tosun, J. ve Iyengar, S. (2017). Family, society and the individual: Determinants of entrepreneurial attitudes among youth in Chennai, South India. Journal of Global Entrepreneurship Research, 7(14), 1-22.

Jayawarna, D., Jones, O. ve Macpherson, A. (2014). Entrepreneurial potential: The role of human and cultural capitals. International Small Business Journal, 32(8), 918-943.

Karimi, S. (2020). The role of entrepreneurial passion in the formation of students' entrepreneurial intentions. Applied Economics, 52(3), 331-344.

Klein, H. J., Wesson, M. J., Hollenbeck, J. R. ve Alge, B. J. (1999). Goal commitment and the goal-setting process: conceptual clarification and empirical synthesis. Journal of Applied Psychology, 84(6), 885.

Kümbül, G, B. (2008). Sosyal girişimciliği etkileyen faktörlerin analizi (Yayınlanmamış Doktora Tezi). Dokuz Eylül Üniversitesi, İzmir.

Leffel, A. ve Darling, J. (2009). Entrepreneurial versus organizational employment preferences: a comparative study of European and American respondents. Journal of Entrepreneurship Education, 12, 79-92.

Ma, C., Ma, Y. ve Lan, X. (2020). The moderating role of social identity and grit in the association between parental control and school adjustment in chinese middle school students. Frontiers in Psychology, 11, 1-13.

Matos, M., Pinto-Gouveia, J. ve Costa, V. (2013). Understanding the importance of attachment in shame traumatic memory relation to depression: The impact of emotion regulation processes. Clinical Psychology \& Psychotherapy, 20(2), 149-165.

McDowell, D. J. ve Parke, R. D. (2005). Parental control and affect as predictors of children's display rule use and social competence with peers. Social Development, 14(3), 440-457.

Michelle, L. (2017). 8 early childhood experiences that continue to affect you even in adulthood. Learning Mind: https://www.learning-mind.com/earlychildhood-experiences/ (Erişim Tarihi: 12.05.2020)

Mueller, B. A., Wolfe, M. T. ve Syed, I. (2017). Passion and grit: An exploration of the pathways leading to venture success. Journal of Business Venturing, 32(3), 260-279.

Naktiyok, A. ve Timuroğlu, M. K. (2009). Öğrencilerin motivasyonel değerlerinin girişimcilik niyetleri üzerine etkisi ve bir uygulama. Atatürk Üniversitesi İktisadi ve İdari Bilimler Dergisi, 23(3), 85-103.

Nikolaus, C. J., Schierer, M., Ellison, B., Eicher-Miller, H. A., Gundersen, C. ve NickolsRichardson, S. M. (2019). Grit is associated with food security among US parents and adolescents. American Journal of Health Behavior, 43(1), 207-218.

Obschonka, M., Hakkarainen, K., Lonka, K. ve Salmela-Aro, K. (2017). Entrepreneurship as a twenty-first century skill: entrepreneurial alertness and intention in the transition to adulthood. Small Business Economics, 48(3), 487-501.

Ohe, S. ve Ohe, T. (1996). Three key experiences of Japanese entrepreneurs during their elementary and secondary school years. Frontiers of Entrepreneurship Research, Wellesley, MA.

Önay, I., Ayas, S., Uğurlu, Ö. Y. ve Önay, M. B. (2017). Psikolojik sermaye ile girişimcilik niyeti ilişkisi. Gazi İktisat ve Işsletme Dergisi, 3(3), 55-66. 
Öngen, D. E. (2006). The relationships between self-criticism, submissive behavior and depression among Turkish adolescents. Personality and Individual Differences, 41(5), 793800 .

Pierro, A., Kruglanski, A. W. ve Higgins, E. T. (2006). Progress takes work: Effects of the locomotion dimension on job involvement, effort investment, and task performance in organizations. Journal of Applied Social Psychology, 36(7), 1723-1743.

Rachmawan, A., Lizar, A. A. ve Mangundjaya, W. L. (2015). The role of parent's influence and self-efficacy on entrepreneurial intention. The Journal of Developing Areas, 49(3), 417-430.

Richter, A., Gilbert, P. ve McEwan, K. (2009). Development of an early memories of warmth and safeness scale and its relationship to psychopathology. Psychology and Psychotherapy: Theory, Research and Practice, 82(2), 171-184.

Sarıçam, H., Çelik, İ. ve Oğuz, A. (2016). Kısa azim (sebat) ölçeğinin türkçeye uyarlanmasıgeçerlik ve güvenirlik çalışması. Uluslararası Türkçe Edebiyat Kültür Eğitim Dergisi, 5(2), 927-935.

Schoon, I. ve Duckworth, K. (2012). Who becomes an entrepreneur? early life experiences as predictors of entrepreneurship. Developmental Psychology, 48(6), 1719-1726.

Sezer, C. (2013). Kariyer olarak girişimcilik ve girişimcilik niyetini etkileyen faktörlerin içerik analizi ile belirlenmesi. Manas Sosyal Araştırmalar Dergisi, 2(2), 49-60.

Sezer, Ö. Ü. T., Uyanık, G., Karabulut, A. G. ve Sazlı, E. K. (2019). 5-6 yaşında çocuğu olan annelerin çocukluk deneyimleri ve öznel mutluluk düzeyleri arasındaki ilişkinin incelenmesi. Kalem Eğitim ve İnsan Bilimleri Dergisi, 9(1), 177-193.

Sharda, P. (2019). Relationship study of GRIT and entrepreneurship. Science, Technology and Development. 8(12), 696-719.

Sharma, L. (2014). Impact of family capital \& social capital on youth entrepreneurship-a study of Uttarakhand state, India. Journal of Global Entrepreneurship Research, 1(4), 1-18.

Shek, D. T. (2007). Perceived parental control based on indigenous Chinese parental control concepts in adolescents in Hong Kong. The American Journal of Family Therapy, 35(2), 123137.

Sığrı, Ü., ve Tığl1, M. (2006). Hofstede'nin" belirsizlikten kaçınma" kültürel boyutunun yönetselörgütsel süreçlerde ve pazarlama açısından tüketici davranışlarına etkisi. Marmara Üüniveristesi, İ.İ.B.F. Dergisi, 21(1), 327-342.

Şahin, S. (2018). Psikolojik danışman adaylarının çocukluk deneyimleri algısının belirlenmesi. Academic Review of Humanities and Social Sciences, 1(1), 62-70.

Şeşen H. ve Basım H. N. (2012). Demografik faktörler ve kişiliğin girişimcilik niyetine etkisi: spor bilimleri alanında öğrenim gören üniversite öğrencileri üzerine bir araştırma. Ege Akademik Bakış, 12 (Özel Sayı). 21-28.

Taner, A. E. (2019). Beliren yetişkinlerin kendini sevme ile öz-yeterlik özelliklerinin çocukluk deneyimleri ve bazı değişkenlere göre incelenmesi (Yüksek lisans tezi). Maltepe Üniversitesi, İstanbul.

Tarhini, A., Teo, T. ve Tarhini, T. (2016). A cross-cultural validity of the E-learning Acceptance Measure (ElAM) in Lebanon and England: A confirmatory factor analysis. Education and Information Technologies, 21(5), 1269-1282. 
TÜİK (2020), https://data.tuik.gov.tr/tr/main-category-sub-categories-sub-components2/. (Erişim tarihi: 19.10.2020).

Vela, J. C., Lu, M. T. P., Lenz, A. S. ve Hinojosa, K. (2015). Positive psychology and familial factors as predictors of Latina/o students' psychological grit. Hispanic Journal of Behavioral Sciences, 37(3), 287-303.

Webb, M., Heisler, D., Call, S., Chickering, S. A. ve Colburn, T. A. (2007). Shame, guilt, symptoms of depression, and reported history of psychological maltreatment. Child Abuse \& Neglect, 31(11-12), 1143-1153.

Williams, L. R., Degnan, K. A., Perez-Edgar, K. E., Henderson, H. A., Rubin, K. H., Pine, D. S., Steinberg, L. ve Fox, N. A. (2009). Impact of behavioral inhibition and parenting style on internalizing and externalizing problems from early childhood through adolescence. Journal of Abnormal Child Psychology, 37(8), 1063-1075.

Wolfe, M. T. ve Patel, P. C. (2016). Grit and self-employment: a multi-country study. Small Business Economics, 47(4), 853-874.

Yener, S. (2018). Sosyolojik kuramlar çerçevesinde aile ve girişimcilik ilişkisi. Anemon Muş Alparslan Üniversitesi Sosyal Bilimler Dergisi, 6(6), 869-878.

ETIKK ve BİLIMSEL İLKELER SORUMLULUK BEYANI
Bu çalışmanın tüm hazırlanma süreçlerinde etik kurallara ve bilimsel atıf gösterme
ilkelerine riayet edildiğini yazar(lar) beyan eder. Aksi bir durumun tespiti halinde Afyon
Kocatepe Üniversitesi Sosyal Bilimler Dergisi'nin hiçbir sorumluluğu olmayıp, tüm sorumluluk
makale yazarlarına aittir. Yazarlar etik kurul izni gerektiren çalışmalarda, izinle ilgili bilgileri
(kurul adı, tarih ve sayı no) burada belirtmişlerdir.
Kurul adı: Burdur Mehmet Akif Ersoy Üniversitesi Girişimsel Olmayan Klinik
Araştırmalar Etik Kurulu
Tarih: 15.04 .2020
No: GO 2020/193

